\title{
Mafic-Ultramafic Large Igneous Provinces (LIPs): Importance of the Pre-Mesozoic record
}

\author{
Ernst Geosciences, 43 Margrave Ave Ottawa, Ontario K1T 3 Y2 Canada. \& Adjunct professor, Dept of Earth Sciences, Carleton University,
} Ottawa, Canada K1S 5B6.Email: Richard.Ernst@ErnstGeosciences.com

\begin{abstract}
Mafic-ultramafic magmatic provinces are termed Large Igneous Provinces (LIPs) if they are large $\left(>10^{5} \mathrm{~km}^{3}\right)$, are emplaced in a short duration (ca. $<5$ myr) (or consist of short duration pulses), and have intraplate characteristics (i.e. are not associated with normal plate boundary processes). This category includes the classic continental flood basalts, oceanic plateaus, bimodal-rift (passive margin) related packages, but also those events, mainly of Phanerozoic-Proterozoic age, where the plumbing system of dykes, sills and layered intrusions has been exposed by erosion. In the Archean, LIPs may be represented by the greenstone belts of the tholeiite-komatiite association. Felsic magmatism is associated with many LIPs and indeed may be dominant in some cases. LIPs are associated with continental breakup, climatic change, extinction events, and major ore deposits especially of the Ni-Cu-PGE type. Continental LIPs occur on average every 20-30 myr since $2.6 \mathrm{Ga}$; the Archean record is too poorly preserved for generalizations. LIPs occur both as isolated single events (e.g., 2055 Ma Bushveld event), as approximately coeval but widely separated events (e.g., $65 \mathrm{Ma}$ Deccan and $62 \mathrm{Ma}$ NAIP), and as regional clusters associated with supercontinent breakup (e.g., the 830-750 Ma events associated with the breakup of the proposed supercontinent Rodinia). The LIP record represents a key tool for constraining Proterozoic paleocontinental reconstructions.
\end{abstract}

\section{Introduction}

\section{Characteristics of Large Igneous Provinces (LIPs)}

Earth history is punctuated by numerous periods during which large volumes of mainly mafic magma were emplaced in the crust and erupted on the surface by processes not associated with 'normal' spreading ridge or subduction environments. These Large Igneous Provinces (LIPs) consist of continental flood basalts, volcanic rifted margins, oceanic plateaus, ocean basin flood basalts (Coffin and Eldholm 1994, 2001, 2005) and their plumbing system components (dykes, sills and layered intrusions) and potential Archean analogues (greenstone belts of the tholeiite-komatiite assemblage) (e.g., Ernst et al., 2005). Submarine ridges, and seamount chains were part of the original definition (Coffin and Eldholm, 1994), but do not fit current definitions that emphasize a short duration of magmatic activity or sharp pulses of activity (e.g. Bryan and Ernst, 2007; "transient LIPs" of Coffin and Eldholm, 2001), and intraplate characteristics for the onset of the event (Bryan and Ernst, 2007). Silicic magmatism is frequently associated, and in some cases, can be of high-volume (e.g., Bryan et al., 2002; Bryan, 2007; Dobretsov, 2005).

\section{Cenozoic-Mesozoic LIPs}

Most research on LIPs has focused on the dramatic flood basalts which characterize Cenozoic-Mesozoic events, both continental flood basalts, and the flood basalts of ocean basins (oceanic plateaus and ocean basin flood basalts). This young record is generally wellpreserved and has been critical to development of many key concepts for LIPs, as discussed below.

Many LIPs have areal and volumetrical extents of greater $1 \mathrm{Mkm}^{2}\left(1 \mathrm{Mkm}^{3}\right)$ (White and McKenzie, 1989; Courtillot and Renne 2003). One of the largest continental LIPs, the Siberian traps have an estimated size of $4 \mathrm{Mkm}^{3}$ (Ivanov, 2007), but this is a minimum because of the difficulties of estimating the intrusive and underplated component of continental LIPs. The largest LIP is Ontong Java, an oceanic plateau in the Pacific Ocean northeast from Australia. With inclusion of related nearby ocean basin flood basalts (Nauru, East Mariana, Pigafetta; Ingle and Coffin, 2004) and assuming original reconstruction with Manihiki and Hikurangi plateaus (Taylor, 2006) the total volume of this LIP is estimated at $59-77 \mathrm{Mkm}^{3}$ (Kerr \& Mahoney, 2007).

The minimum size criterion for LIPs is controversial. Herein is used the original criterion of an areal extent of at least $0.1 \mathrm{Mkm}^{2}$ (Coffin and Eldholm, 1994, 2001; Ernst and Buchan, 2001a; Ernst et al., 2005; Bryan and Ernst, 2007); note, however that others, such as Courtillot and Renne (2003), prefer a more restrictive criterion of an areal extent of $1 \mathrm{Mkm}^{2}$ with a volume of $1 \mathrm{Mkm}^{3}$, and Sheth (2006) suggests a smaller size of $50,000 \mathrm{~km}^{2}$.

The short duration of emplacement is evident from the main stage of flood basalt magmatism which consist of monotonous packages up to several $\mathrm{km}$ thick of large tabular flow units and often lacking any significant interlayed sediments; high precision dating confirms typical emplacement in 1-5 myr (Jerram and Widdowson, 2005; Courtillot and Renne, 2003).

Continental flood basalts are dominately mafic (dominantly tholeiitic) with minor ultramafic component (picritic) and transitional-alkaline component lower in the sequence and felsic magmatism becomes more significant higher in the sequence (Borisenko et al., 2006; Gibson, 2002, Jerram and Widdowson, 2005; Bryan, 2007). Bimodal magmatism is associated with rifted margins. Oceanic plateaus and ocean basin flood basalts have variable mantle sources, and continental flood basalts represent the same mantle sources with the added element of interaction with continental lithosphere: mantle and crust (e.g., Hofmann, 1997; Condie, 2003, Hawkesworth and Scherstén, 2007; Kerr and Mahoney, 2007).

Other key concepts developed from the Mesozoic-Cenozoic record are the link between LIPs and continental breakup (Courtillot et al., 1999), LIPs and major extinction events (Saunders, 2005; Courtillot and Renne, 2003), LIPs and Ni-Cu-PGE ore deposits (Naldrett, 1997, 1999) and in some cases, LIPs and domal uplift (e.g., Saunders et al., 2007).

The Cenozoic-Mesozoic LIP record represents only a fraction of Earth's LIP history, and the preserved style of LIP activity varies with time (Ernst et al., 2001a, Ernst et al., 2005). As mentioned above, the flood basalts of Mesozoic and Cenozoic age are typically the best preserved and best studied. In contrast, the pre-Mesozoic record is more deeply eroded and therefore, LIPs of Paleozoic and 
Proterozoic age are typically recognized by flood basalt remnants and the exposed plumbing system represented by giant dyke swarms, sill provinces and layered intrusions. Oceanic LIPs are incompletely preserved during ocean closure and occur as obducted deformed sequences. In the Archean, the most promising LIP candidates are greenstone belts containing tholeiite-komatiite sequences.

In the remainder of this contribution, we focus on the importance of extrapolating the LIP record back beyond the Mesozoic. We review key characteristics of this older record. We also take the "long-view" (looking at observations based on the LIP record through time as a whole), and discuss the use of the Paleozoic and Proterozoic record in paleocontinental reconstructions. We also emphasize the importance of expanding research on this older LIP record.

\section{Pre-Mesozoic LIPs}

The global bar code of LIP is well populated with more than 150 events (Figure 1), and it can be seen that there are few significant gaps in the post $2.6 \mathrm{Ga}$ record. Since $2.6 \mathrm{Ga}$, the emplacement rate has been about 1 LIP every 20 myr. A comparison with earlier versions of this diagram (e.g., Ernst \& Buchan, 2001a; Ernst et al., 2005) confirms a pattern in which previously LIP-free gaps are gradually being filled-in as mafic units (particularly dyke swarms and sill provinces) around the world continue to be precisely dated.

\section{Paleozoic-Proterozoic LIPs}

Pre-Mesozoic LIPs, are more greatly affected by erosion which largely removes their flood basalts, exposing their plumbing system. Therefore, continental LIPs of Paleozoic and Proterozoic age typically consist of the giant dyke swarms (defined as those $>300 \mathrm{~km}$ long), sill provinces, large layered intrusions, and remnants of flood basalts (Ernst \& Buchan, 1997, 2001a). Like their Cenozoic-Mesozoic flood basalt equivalents, this class of intrusive-dominated LIPs has large areal extents and volumes, exhibits short duration pulses and has 'intraplate' character, consistent with definition as a LIP (Coffin \& Eldholm, 1994, 2001, 2005; Ernst et al., 2005; Bryan and Ernst, 2007).

\section{Archean LIPs}

Erosional remnants of Archean flood basalt provinces include the Fortescue sequence of the Pilbara craton in Australia and the Ventersdorp sequence of the Kaapvaal craton in southern Africa (Eriksson et al., 2002). However, most Archean volcanic rocks occur as deformed and fault-fragmented packages termed greenstone belts (de Wit \& Ashwal, 1997, 1998). One class of greenstone belts contains mafic to silicic igneous rocks with calc-alkaline geochemical signatures, and is interpreted to be arc related. The other major class of greenstone belts consists of tholeiite-komatiite sequences and these are the best candidates for being remnants of Archean LIPs. In terms of setting, these include accreted oceanic plateaus and those emplaced in a continental platform setting (e.g., Thurston and Chivers, 1990; Condie, 2001).

In general, deformation and faulting generally prevent the tracing of Archean tholeiite-komatiite greenstone belts over LIP-scale areas. An important exception occurs in the Rae craton of northern Canada where the $c a$. 2700 Ma Prince Albert, Woodburn Lake, and Mary River Groups define a linear belt, which extends for a distance of $1500 \mathrm{~km}\left(>0.2 \mathrm{Mkm}^{2}\right)$, and may be linked with a mantle plume and/or a late Archean breakup margin (e.g., McHattie et al., 2004). Another consideration is that not all komatiites are associated with an extensional environment. There is some evidence for the production of komatiites by melting of wet mantle under subduction conditions (e.g., Parman \& Grove, 2005), although Arndt et al. (1998) argue against widespread application of the 'wet' komatiite model.

\section{Insights from the Pre-Mesozoic LIP record}

As we take the longer view, there are insights from each era (Cenozoic-Mesozoic, Paleozoic-Proterozoic, Archean) that together can contribute to a deeper understanding of LIPs. The classic view of LIPs was developed using the young flood basalt record of Cenozoic-Mesozoic time. The more deeply eroded Paleozoic-Proterozoic LIP record is useful for understanding the plumbing system of LIPs. The Archean record is useful for evaluating differences in flood basalt style at a much earlier stage in Earth's history. However, at our present level of understanding, there is such uncertainty about the recognition of Archean LIPs, that for the remainder of this paper we will focus on Paleozoic-Proterozoic LIPs. 


\section{LIP plumbing system}

There are many advantages of stripping off the flood basalts and seeing the exposed LIP plumbing system, as revealed by the Paleozoic-Proterozoic record. One area of fruitful inquiry is the following. Since LIP magmas are derived from the mantle, then the plumbing system should contain information about the locations where mantle-derived magma enters the crust, and also how that magma is distributed within the crust and subsequently erupted on surface (Ernst et al., 2005). The elements of this plumbing system are giant dyke swarms, sills, layered intrusions and magmatic underplate.

Flood basalts are mainly fissure-fed, i.e. fed by dykes, rather than by central volcanoes (e.g., Jerram and Widdowson, 2005). So the major dyke swarm beneath the flood basalt pile are especially important. Studies have indicated that major dyke swarms can be fed laterally by magma moving sideways through the crust along a level of neutral buoyancy (Halls, 1982; Ernst and Buchan, 1997; Wilson and Head, 2002). This means that the mantle source areas for major dyke swarms (and the flood basalts that they feed) may be localized beneath the end of a swarm rather than distributed continuously underneath the swarm. This idea is most interesting when applied to giant radiating dyke swarms, such as the $1270 \mathrm{Ma}$ Mackenzie and 2215 Ma Ungava swarms of northern Canada. Laterally-propagating dykes can transport magma from the plume centre (marked by the focal point of the radiating swarm) and potentially feed sills and lava flows at long distances (more than $1000 \mathrm{~km}$ ) away (e.g., Buchan et al., 1998; Ernst and Buchan, 1997). Such a model supports the perhaps surprising notion that a package of sills or lava flows are not necessarily fed from the immediately underlying mantle. If they have been transported laterally in dykes, then their mantle source area may lie at the other end of the swarm, perhaps more than 1000 km away.

Another important aspect of the plumbing system of LIPs is the nature and distribution of layered intrusions. The 2055 Ma Bushveld intrusion of South Africa is the world's largest layered igneous intrusion, and is regarded as the intrusive equivalent of a flood basalt province, given its extensive volume $0.38 \mathrm{Mkm}^{3}$ and short duration of emplacement ( 75 Kyr) (Hatton, 1995; Eales \& Cawthorn, 1996; Cawthorn \& Walraven, 1998; Kinnaird, 2005). Furthermore, the event is part of more widely-distributed coeval magmatism in the Kaapvaal craton, which includes the Molopo Farms layered intrusion, the Okwa basement complex and the Phalaborwa carbonatite (e.g., Mapeo et al., 2006; Reichardt, 1994; Kinnaird, 2005). LIP-type layered intrusions such as Bushveld are extremely important to the mining industry, and understanding the plumbing system which connects layered intrusions to mantle source areas and that which connects layered intrusions to surface lavas are key to understanding ore deposit potential (e.g., Naldrett, 1997, 1999).

The Cenozoic-Mesozoic record affirms that felsic volcanism is a significant component of most LIP events in the young record (Bryan, 2007). It is therefore expected that felsic magmatism would also be a part of the pre-Mesozoic record, a fact confirmed by a detailed compilation of the LIP record through time (Ernst and Buchan, 2001a). An interesting case history is the extensive 825-750 Ma mafic-ultramafic intrusions and coeval granitic magmatism which are widely distributed in South China. This magmatism has traditionally been linked to an arc setting (e.g., Zhou et al., 2002), but a compelling case has been made for this mafic and felsic intrusive magmatism to represent a LIP(s) of possibly 4 distinct ages, 825, 800, 780 and $755 \mathrm{Ma}$ associated with 'superplume' arrival and linked with the breakup of Rodinia (Li et al., 2003). Another example is the granite magmatism associated with the early $2770 \mathrm{Ma}$ stage of Fortescue flood basalt magmatism in the Pilbara craton (Nelson et al., 1999). The isotopic and trace element characteristics of LIP-related felsic magmatism can be quite variable, because these felsic magmas are derived from partial melting of lower crust and will therefore inherit some of the geochemical characteristics of the protolith (e.g., Bryan et al., 2002).

\section{Finding the missing oceanic LIP record}

The rate of LIP production is essentially constant since the end of the Archean (Figure 1), with a rate of about 1 LIP per $20 \mathrm{Myr}$ (Ernst and Buchan 2002). However, in the past $200 \mathrm{Myr}$, the LIP rate jumps to an average of almost 1 per $10 \mathrm{Myr}$ (curve A). This change reflects the importance of the oceanic LIP record which is largely lost during subduction and ocean closure in pre-200 Myr time (Ernst and Buchan, 2005). Dotted curve B (Figure 1) includes only continental LIPs and continues the 1 per $20 \mathrm{Myr}$ rate of 2500-200 Ma. Comparison between curves A and B implies that the rate of oceanic LIP production since $200 \mathrm{Ma}$ is also about 1 per $20 \mathrm{Myr}$ and that this record is poorly preserved in pre-200 Ma time. Since the rate of continental LIPs is fairly constant from back to $2.5 \mathrm{Ga}$, then perhaps the rate of oceanic LIP production is also relatively constant over that time, and therefore, perhaps the rate of 1 per $20 \mathrm{Myr}$ (measured for the last $200 \mathrm{Ma}$ ) can be applied back to $2.5 \mathrm{Ga}$. If so, then the total number of LIPs since $2.5 \mathrm{Ga}$ is about 250 , about half of which are continental and half are oceanic LIPs.

Most of this oceanic LIP record is 'missing', and has not been identified. This is presumably due to poor preservation during ocean closure. However, there is potential for identifying surviving fragments of these oceanic LIPs within orogenic belts. For instance, remnants of Late Paleozoic to Mesozoic accreted oceanic plateaus are now being recognized around the north Pacific margins (e.g., Okhotsk, NE Russia; Sorachi, Japan; Piñon Formation, Ecuador; Cache Creek and Wrangellia, Canada) (see summary in Ernst and Buchan, 2001a; Bogdanov and Dobretsov, 2002). A related point is the apparent shortage of ancient volcanic rifted margins, with respect to the present day where up to $90 \%$ of the global rifted margins are volcanic (Menzies et al., 2002). Coffin \& Eldholm (2001) noted that "more ophiolite fragments may be obducted sections of volcanic passive margins and oceanic plateaus than we now suppose".

It should also be noted that while the average rate of continental LIP production is about 1 per $20 \mathrm{Myr}$ (Figure 1), the average interval between events is probably closer to $30 \mathrm{Myr}$, because of many cases where different events are occurring at the same time (pers. comm. N. Dobretsov, 2006). This relates to the topic of LIP clustering discussed later. A time series analysis of the LIP record revealed weak cycles of 730-500, 330, 170, 100 and $30 \mathrm{Myr}$ (Prokoph et al., 2004), which were also broadly similar to those cycles identified by Isley and Abbott (2002) on an independent dataset.

\section{Assessing the origin of LIPs}

The debate on the origin of LIPs has intensified in recent years (e.g., Anderson, 2005; Campbell, 2005, Saunders, 2005; Foulger, 2007; Campbell and Kerr, 2007). Traditionally, LIPs were linked to the ascent of a plume from the deep mantle and its arrival and partial melting at the lithosphere. However, in recent years this consensus has been strongly challenged, and plume-alternative mechanisms have been proposed for most Cenozoic-Mesozoic examples. For instance, although the Siberian traps have been linked with deep mantle plume origin (e.g Saunders et al., 2007), non-plume origins have been offered: such as delamination (Elkins-Tanton \& Hager, 2000, Elkins-Tanton, 2005), and subduction which introduces water into the mantle source area allowing for enhanced melting (Ivanov, 2007).

From a broader perspective, the current list of main LIP generation models includes: deep mantle plume, rifting above hot mantle, delamination, bolide impact, and edge-driven convection (e.g., Saunders et al., 2007). Additional models that apply to smaller scale magmatic events (probably sub-LIP scale) include back arc rifting and over-riding of a spreading ridge. A plume origin is most compelling for LIPs associated with broad domal uplift, a radiating dyke swarm, and a central region of high-Mg magmatism marking a hot central axis. Short duration LIPs $(<5 \mathrm{Ma})$ are typically associated with both plume arrival and lithospheric delamination. Longer duration LIPs ( $>25 \mathrm{Ma})$ and especially those that have a linear / elongate 
spatial distribution suggest a back arc, or rift setting. Double-pulse LIPs can indicate initial plume arrival followed by rifting. Key parameters for classifying LIPs in terms of setting and origin are: the total magma volume (or, more easily estimated, the areal extent), the age distribution (single vs. multiple pulses, continuous), maximum $\mathrm{MgO}$ content, the geometry of associated dyke swarms (radiating or linear), geographic distribution of the LIP (elongate or circular), link with rifting / breakup, and link with regional uplift. Geochemical / isotopic parameters are useful but not definitive (e.g., Hawkesworth and Scherstén, 2007).

Much of the debate on the cause of LIPs has taken place with respect to Cenozoic-Mesozoic LIPs. And indeed there is potential to use the architecture of the flood basalt pile, e.g., subtle systematic sideways shifts in the position of maximum volcanism through the duration of the LIP event, in order to locate the underlying mantle source (e.g., Jerram and Widdowson, 2005). In addition, the plumbing system exposed in most Proterozoic LIP, also has great potential to help discriminate between possible causes of a LIP. For instance, if a large $1 \mathrm{Mkm}^{2}$ province can be shown to be fed from a single localized region (say $500 \mathrm{~km}$ in diameter), this would favour a plume or delamination origin. If the interpreted source region is elongate or linear, then the mechanism would likely relate to a plate or other lithospheric boundary. Increased attention to characterizing the plumbing system (dykes, sills and layered intrusions) of a LIP will undoubtedly contribute to our understanding of the plume or non-plume cause of that LIP.

Here is an example of a compressional setting for a LIP. The large $c a .1100 \mathrm{Ma}$ Keweenawan LIP in the Lake Superior region of central Laurentia, which consists of about $15 \mathrm{~km}$ of mainly basaltic magma emplaced into a intracontinental rift, did not lead to breakup because the region was under compression at the same time due to continental collision associated with the nearby Grenville orogeny (e.g., Manson and Halls, 1997). This example confirms that LIPs can be emplaced into a collisional setting. On a broader view, the Umkondo event of the Kalahari craton is coeval with the Keweenawan event, but paleomagnetic data confirms that they must lie on opposite sides of the evolving Grenville orogen (Hanson et al., 2004). Therefore, if the coeval Keweenawan and Umkondo events are genetically related, they must be linked to a common lower mantle source, i.e. deeper than the region involved in continent-continent collision which is dominantly an upper mantle process.

\section{Finding ore deposits}

LIPs are a key target for magmatic Ni-Cu-PGE, Cr, Fe-Ti-V and other deposit types (Naldrett, 1997, 1999; Pirajno, 2000; Schissel and Smail, 2001; Borisenko et al., 2006; Eckstrand and Hulbert, 2007), and the record clearly shows this important association is not restricted to any particular time period. World-class (tier 1 ) Ni-CuPGE deposits are associated with the 250 Ma Noril'sk bodies of the Siberian traps, but also the 825 Ma Jinchuan intrusions associated with a widespread LIP in South China (Li et al., 2005) and the 2055 Ma Bushveld of southern Africa (e.g., Naldrett, 1997). In addition, silicic LIPs (Bryan et al., 2002; Dobretsov, 2005) may be associated with Olympic Dam-type deposits (e.g., Campbell, 1998; Corriveau, 2007).

There are additional intrusive types (and their ore deposits) associated with LIPs. Specifically there is a spatial association with kimberlites (e.g., Agashev et al., 2004; Kjarsgaard, 2007) and carbonatites (Bell, 2001). In addition to orthomagmatic ore deposits, the emplacement of LIPs produces a large thermal anomaly and convection in the crust. This large scale fluid circulation engenders a variety of hydrothermal systems that form ore deposits (e.g., Pirajno, 2000).

The recognition that LIPs are important targets for ore deposits, and the recognition that continental LIPs occur at an average rate of 1 per $20 \mathrm{Myr}$, since the end of the Archean means a greatly expanded list of exploration targets, possibly 130 since $2.6 \mathrm{Ga}$. This wealth of possible exploration targets needs to be refined by studies to determine which of these events are more economically prospective (Ernst, 2007). Then each of the LIPs of potential economic interest need to be further evaluated to identify more localized target areas for exploration within the LIP.

\section{Characterizing multiple-pulse LIPs}

Many Phanerozoic and Proterozoic events consist of multiple pulses of magmatism. In some cases, only a single large pulse is observed (such as with the 1267 Ma Mackenzie event of northern Canada). However, in many cases two pulses are observed (Ernst and Buchan, 2002). The initial pulse is often inferred to have a plume origin, but the second pulse can be linked to the onset of rifting (Campbell, 1998). In other cases, even more pulses are observed. For instance, the Laurentian Iapetus-margin related events (Puffer, 2002; Ernst and Buchan, 2004, Andreasson et al., 2007) have pulses at $615,590,563 \mathrm{Ma}$. It is possible that these multiple pulses represent sequential breakup of Laurentia: Baltica from Laurentia (starting with the $615 \mathrm{Ma}$ LIP), and Amazonia from Laurentia at ca 570 Ma (starting with the $590 \mathrm{Ma} \mathrm{LIP}$ ), and the Dashwoods terrane from Laurentia at $c a$ 550-540 Ma (starting with the $563 \mathrm{Ma}$ LIP) (Bingen et al., 1998; Waldron and van Staal, 2001; Cawood et al., 2001; Ernst and Buchan, 2004). Multiple pulses are also characteristic of tholeiite-komatiite packages in many Archean greenstone belts. For example, the Abitibi belt has pulses of tholeiitic-komatiitic magmatism at 2750-2735 Ma, 2725-2720 Ma, 2718-2710 Ma, and 2710-2703 Ma (Ayer et al., 2002). The Fortescue flood basalt of the Pilbara craton has pulses at ca. 2770, 2720, and $2690 \mathrm{Ma}$ (Thorne \& Trendall, 2001; Blake et al., 2004; Eriksson et al., 2002). Whether these represent multiple pulses of a single LIP or the juxtaposition of separate LIPs remains to be determined in each case.

However, it should be noted that the young (Cenozoic-Mesozoic) LIP record seems to have fewer multiple-pulse LIPs, but this may be related to a better preserved regional geological context which allows multiple pulses to be resolved into independent events. As an illustration of this point we consider the magmatism which can be linked to the breakup history of India within Gondwana. Southwestern India contains dyke swarms of $\mathrm{K}-\mathrm{Ar}$ age $144+/-6 \mathrm{Ma}$, 105+/-2 Ma, 81+/-3 Ma and 61+/-9 Ma (Radhakrishna et al., 1990). This dataset could appear to be evidence for a single multi-pulse LIP with ages 144, 105, 81 and 61 Ma. However, (and keeping in mind that these are K-Ar ages with true uncertainties greater than the analytical uncertainties), these dyke swarms can actually be linked to three different known breakup events affecting India: $c a$. 144 (\& possibly $c a$. 105) Ma dykes with separation of Antarctica at about 128-116 Ma, the $c a .81 \mathrm{Ma}$ dykes with separation of Madagascar after mantle plume arrival at $88 \mathrm{Ma}$, and the $c a$. $61 \mathrm{Ma}$ age with separation of the Seychelles-Mascarene microcontinent in association with Deccan magmatism at $65 \mathrm{Ma}$ (Storey, 1995; Ernst et al., 2001b, Jerram and Widdowson, 2005).

\section{Recognition of coeval but independent LIPs}

Many LIPs seem to be of regional-scale and to be linked to a single centre of activity, but at least some are present on so many different blocks as to suggest that they are independent LIPs generated from more than one centre. In the younger record, there are many examples of such coeval but independent LIPs (plume-clusters of Ernst \& Buchan, 2002; cf. "superplume" of Larson, 1991). For example, LIPs at $\sim 130 \mathrm{Ma}$ include the Paraná-Etendeka of South America-Africa breakup, the Trap dykes of southern Greenland, the Bunbury basalt of southwestern Australia, and the initial pulse of the High Arctic Large Igneous province. A second example of a LIP cluster is the essentially coeval 65 Ma Deccan and 62 Ma North Atlantic LIPs of India and Europe-Greenland, respectively. But this can also be demonstrated at older times. For instance, 1380 Ma magmatism occurs in northern Greenland, and also in two places in western Canada about $1000 \mathrm{~km}$ apart (Ernst et al., 2007). These two distinct nodes of 1380 Ma magmatism in Lauarentia (Greenland and western Canada) are so widely separated (about $5000 \mathrm{~km}$ ), that they must represent independent events. 
Such LIP clusters are now catalogued at $65-62,90,120,133$, $1115-1070,1270,1380$, and $1460 \mathrm{Ma}$, and possibly at 755, 780 and $825 \mathrm{Ma}$ (Ernst and Buchan, 2002; Ernst et al., 2007). Do these coeval but widely separated and probably independent LIPs simply represent stochastic age matches of a random and frequent flux of mantle generated LIP events? Or does this indicate a global-scale process, probably implying a deep mantle/core cause.

\section{Identifying LIP 'fragments'}

LIPs are characteristically associated with continental breakup or attempted continental breakup. And so it is not surprising that preMesozoic LIPs can be intensely fragmented by continental breakup such that portions of a single LIP end up on different blocks. A LIP can also be 'fragmented' by erosion which removes the semicontinuous volcanic flood basalt cover and leaves the elements of the plumbing system (dykes, sills and layered intrusions) as widely scattered fragments (Bryan and Ernst, 2007). In many cases, the units that are dated and can be grouped as a distinct magmatic event, will be of insufficient volume to qualify as a LIP, even if they actually represent a 'fragment' of a LIP. Therefore, it is important to ask whether there are characteristics of such units that can identify them as a LIP 'fragment'. It should be possible to use geochemistry to identify LIP membership. Many attempts have been made to identify plume-related LIPs using geochemistry, in the context of identifying "intraplate" composition. But as recently pointed out by Hawkesworth and Scherstén (2007) magmatism of a range of scales (including sub-LIP scale) may also exhibit intraplate chemistry. Abbott and Isley (2002) indicate that "superplume"-related layered intrusions should have high PGE and Cr contents. A key 'field' criteria for LIP-related dykes is average dyke width. Experience with Canadian Shield dykes suggests that dyke swarms with average dyke width $>10 \mathrm{~m}$ are not formed in a subduction or spreading ridge setting, and are therefore candidates for LIP membership (Ernst et al., 1995). Abbott and Isley (2002) suggest that swarms belonging to a "superplume" event (defined by them as a LIP with an areal extent of at least $0.41 \mathrm{Mkm}^{2}$ ) should have a maximum dyke width of $>70 \mathrm{~m}$. Similar physical criteria also need to be developed to determine whether an isolated sill is LIP related.

\section{Proterozoic paleocontinental reconstructions using LIPs}

A grand dream in geology is to obtain reliable paleocontinental reconstructions through time. Reconstructions are well-established through Cenozoic and Mesozoic time where ocean floor is preserved. Closing of the central Atlantic ocean allows restoration of the 200 Ma CAMP LIP with components (mainly dykes and sills, and minor preserved volcanism) in North America, South America, Europe, and Africa. As another example, the two pieces of the $\sim 132$ Ma LIP, the Paraná of South America and the Etendeka of southwest Africa are restored by closure of the South Atlantic. In contrast, Phanerozoic reconstructions are less robust and few constraints exist for Proterozoic reconstructions (e.g., Buchan et al., 2001). Fortunately, the LIP record can play a key role in constraining Precambrian reconstructions. First of all, progress is being made in comparing the key paleomagnetic poles of units on different blocks in order to constrain the relative positions of these blocks (e.g., Buchan et al., 2001; Wingate et al., 2002; Meert, 2002; Pisarevsky et al., 2003). Many of the key units used for paleomagnetic study are LIPrelated dykes and sills, because diabase dykes and sills are wellbehaved paleomagnetically. More recently, a new 2-part approach has been proposed (Bleeker and Ernst, 2006). The first part of the technique is comparison of the ages of LIPs present on different blocks. Specifically a 'bar code' presentation of those ages is constructed and compared. Those pairs of blocks with multiple age matches in a given interval were probably nearest neighbors during that time interval. The second step is to use the geometry of dykes swarms (linear, radiating) as precise piercing points to orient the blocks which had been previously determined to be nearest neighbors. Specifically, blocks can be oriented to restore an overall radiating dyke swarm pattern or to align components of a linear dyke swarm pattern.

\section{Conclusions}

Earth history has been punctuated by events during which large volumes of mafic and generally subordinate silicic and ultramafic magmas were generated and emplaced by processes distinct from those observable at normal plate boundaries. Large Igneous Provinces (LIPs) are the expression of these anomalous magmatic events. However, few LIPs have been fully characterized in terms of their size, the variation in melt emplacement rate throughout the LIP event, the geochemical character and inferred distribution of mantle source areas, the plumbing system for emplacing and distributing magma in the crust, and links with ore deposits. An important frontier is the pre-Meosozoic record consisting of Paleozoic-Proteorzoic events which tend to be deeply eroded and which expose the LIP plumbing system, and potential Archean analogues (greenstone belts of the tholeiite-komatiite association). We are at an exciting time in terms of research on LIPs - of particular interest is the older record where the ongoing geochronology programs are recognizing that many events are far more widely distributed than previously realized. Expansion of research on the pre-Mesozoic LIP record will help our understanding of the characteristics and processes related to Large Igneous Provinces through time.

\section{Acknowledgements}

I thank the participants at the IAVCEI International Conference on Continental Volcanism, held in Guangzhou, China, May 14-18, 2006 for helpful discussions on this topic, and Yigang $\mathrm{Xu}$, for encouragement in writing this paper. The International Association of Volcanology and Chemistry of the Earth's Interior (IAVCEI) has established the LIPs Commission which maintains a webpage with up-to-date information on large igneous provinces (see http://www. largeigneousprovinces.org) (see also www.mantleplumes.org).

\section{References}

Abbott, D.H. and Isley, A.E., 2002. The intensity, occurrence, and duration of superplume events and eras over geological time. Journal of Geodynamics, v. 34, pp. 265-307.

Agashev, A.M., Pokhilenko, N.P., Tolstov, A.V., Polyanichko, V.V., Mal'kovets, V.G., and Sobolev, N.V., 2004. New age data on kimberlites from the Yakutian diamondiferous province. Doklady Earth Sciences v. 399 , no. 8, pp. $1142-1145$.

Arndt, N, Ginibre, C., Chauvel, C. Albarède, F., Cheadle, M., Herzberg, C., Jenner, G., and Lahaye, Y., 1998. Were komatiites wet? Geology, v. 26, pp. 739-742.

Anderson D.L., 2005. Large igneous provinces, delamination, and fertile mantle. Elements, v. 1, pp. 271-275.

Andreasson, P-G, Buchan, K.L., Shumlyanskyy, L.V., and Ernst, R.E., 2007. The Volynian flood basalt province and coeval (Ediacaran) magmatism in Baltoscandia and Laurentia. Ukrainian Mineralogy Journal (submitted).

Ayer, J., Amelin, Y., Corfu, F., Kamo, S., Ketchum, J., Kwok, K., and Trowell, N., 2002. Evolution of the southern Abitibi greenstone belt based on $\mathrm{U}-\mathrm{Pb}$ geochronology; autochthonous volcanic construction followed by plutonism, regional deformation and sedimentation. Precambrian Research, v. 115 , pp. 63-95.

Bell, K., 2001. Carbonatites: relationship to mantle-plume activity, In: Ernst, R.E. and Buchan, K.L. (eds.), Mantle Plumes: Their Identification Through Time. Geological Society of America Special Paper 352, pp. 267-290.

Bingen, B., Demaiffe, D., and van Breemen, O., 1998. The 616 Ma old Egersund basaltic dike swarm, SW Norway, and Late Neoprtoterozic opening of the Iapetus Ocean. Journal of Geology, v. 106, pp. 565-574. 
Blake, T.S., Buick, R., Brown, S.J.A., and Barley, M.E., 2004. Geochronology of a Late Archaean flood basalt province in the Pilbara Craton, Australia: constraints on basin evolution, volcanic and sedimentary accumulation, and continental drift rates. Precambrian Research, v. 133, pp. 143-173.

Bleeker W. and Ernst R., 2006. Short-lived mantle generated magmatic events and their dyke swarms: The key unlocking Earth's paleogeographic record back to $2.6 \mathrm{Ga}$. In: Hanski, E., Mertanen, S., Rämö, T., and Vuollo, J. (eds.), Dyke Swarms - Time Markers of Crustal Evolution. A.A. Balkema Publishers, Rotterdam, pp. 3-26.

Bogdanov, N.A. and Dobretsov, N.L., 2002. The Okhotsk volcanic oceanic plateau. Russian Geology and Geophysics, v. 43, no. 2, pp. 87-99.

Borisenko, A.S., Sotnikov, V.I., Izokh, A.E., Polyakov, G.V., and Obolensky, A.A., 2006. Permo-Triassic mineralization in Asia and its relation to plume magmatism. Russian Geology and Geophysics, v. 47, no. 1, pp. 166-182.

Bryan, S.E., Riley, T.R., Jerram, D.A., Leat, P.T., and Stephens, C.J., 2002. Silicic volcanism: an under-valued component of large igneous provinces and volcanic rifted margins. In: Menzies, M.A., Klemperer, S.L., Ebinger, C.J., Baker, J. (eds.), Magmatic Rifted Margins. Geological Society of America Special Paper 362, pp. 99-118.

Bryan, S. and Ernst, R.E., 2007. Revised definition of Large Igneous Provinces (LIPs). Earth-Science Reviews (in press).

Bryan, S.E., 2007. Silicic Large Igneous Provinces. Episodes, v.30, no.1, pp. 20-31.

Buchan, K.L., Mortensen, J.K., Card, K.D., and Percival, J.A., 1998. Paleomagnetism and $\mathrm{U}-\mathrm{Pb}$ geochronology of diabase dyke swarms of Minto Block, Superior Province, Quebec, Canada. Canadian Journal of Earth Sciences, v. 35, pp. 1054-1069.

Buchan, K.L., Ernst, R.E., Hamilton, M.A., Mertanen, S., Pesonen, L.J., and Elming, S. ̊., 2001. Rodinia: the evidence from integrated paleomagnetism and U-Pb geochronology. Precambrian Research, v. 110, pp. 9-32.

Campbell, I.H., 1998. The mantle's chemical structure: insights from the melting products of mantle plumes. In: Jackson, I.N.S. (ed.), The Earth's Mantle: Composition, Structure and Evolution. Cambridge University Press, New York, pp. 259-310.

Campbell, I.H., 2005. Large igneous provinces and the mantle plume hypothesis. Elements v. 1, pp. 265-269.

Campbell, I.H. and Kerr, A.C., 2007. The Great Plume Debate: Testing the Plume Theory. Chemical Geology (in press).

Cawood, P.A., McCausland, P.J.A., and Dunning, G.R., 2001. Opening Iapetus: constraints from the Laurentian margin in Newfoundland. Geological Society of America, Bulletin, v. 113, pp. 443-453.

Cawthorn, R.G. and Walraven, F., 1998. Emplacement and crystallization time for the Bushveld Complex. Journal of Petrology, v. 39, pp 1669-1687.

Coffin, M.F. and Eldholm, O., 1994. Large igneous provinces: crustal structure, dimensions, and external consequences. Reviews of Geophysics, v. 32, pp. $1-36$

Coffin, M.F. and Eldholm, O., 2001. Large Igneous Provinces: progenitors of some ophiolites?" In: Ernst, R.E., and Buchan, K.L. (eds.), Mantle Plumes: Their Identification Through Time. Geological Society of America Special Paper 352, pp. 59-70.

Coffin, M.F. and Eldholm, O., 2005. Large igneous provinces. In: Selley, R.C., Cocks, R., and Plimer, I.R. (eds.), Encyclopedia of Geology. Elsevier, Oxford, pp. 315-323.

Condie, K.C., 2001. Mantle Plumes and Their Record in Earth History. Cambridge University Press, $306 \mathrm{p}$.

Condie, K.C., 2003. Incompatible element ratios in oceanic basalts and komatiites: tracking deep mantle sources and continental growth rates with time. Geochemistry, Geophysics, Geosystems. G3 4(1), 1005.

Corriveau, L., 2007. Iron oxide copper-gold deposits: a Canadian perspective. In: Goodfellow, W.D. (ed.), Mineral Deposits of Canada: A Synthesis of Major Deposit-types, District Metallogeny, the Evolution of Geological Provinces, and Exploration Methods. Special Publication 5, Mineral Deposits Division, Geological Association of Canada (in press).

Courtillot, V.E. and Renne, P.R., 2003. On the ages of flood basalt events: Comptes Rendus Geoscience, v. 335, pp. 113-140.

Courtillot, V., Jaupart, C., Manighetti, I., Tapponnier, P., and Besse, J., 1999. On causal links between flood basalts and continental breakup. Earth and Planetary Science Letters, v. 166, pp. 177-195.

de Wit, M.J., and Ashwal, L.D. (eds.), 1997. Greenstone Belts. Clarendon, UK, 809 p.

de Wit, M.J., and Ashwal, L.D., 1998. On Archean granites, greenstones, cratons and tectonics: does the evidence demand a verdict? Precambrian Research, v. 91, pp. 181-226.
Dobretsov, N.L., 2005. 250 Ma large igneous provinces of Asia: Siberian and Emeishan traps (plateau basalts) and associated granitoids. Russian Geology and Geophysics, v. 46 no. 9, pp. 870-890.

Eales, R.V. and Cawthorn, R.G., 1996. The Bushveld Complex. In: Cawthorn R.G. (ed.), Layered Intrusions. Elsevier, Amsterdam, pp 181-229.

Eckstrand, O.R. and Hulbert, L., 2007. Magmatic Nickel-Copper-Platinum Group Elements Deposits. In: Goodfellow, W. D. (ed.), Mineral Deposits of Canada: A Synthesis of Major Deposit-types, District Metallogeny, the Evolution of Geological Provinces, and Exploration Methods. Special Publication 5, Mineral Deposits Division, Geological Association of Canada (in press).

Elkins-Tanton, L.T., 2005. Continental magmatism caused by lithospheric delamination. In: Foulger, G.R., Natland, J.H., Presnall, D.C., and Anderson, D.L. (eds.), Plates, Plumes and Paradigms. Geological Society of America Special Paper 388, pp. 449-462.

Elkins-Tanton, L.T., and Hager, B.H., 2000. Melt intrusion as a trigger for lithospheric foundering and the eruption of the Siberian flood basalt. Geophysical Research Letters, v. 27, pp. 3937-3940.

Eriksson, P.G., Condie, K.C., van der Westhuizen, W., van der Merwe, R., de Bruiyn, H., Nelson, D.R., Altermann, W., Catuneanu, O., Bumby, A.J., Lindsay, J., and Cunningham, M.J., 2002. Late Archaean superplume events; a Kaapvaal-Pilbara perspective. Journal of Geodynamics, v. 34, pp. 207-247.

Ernst, R.E., 2007. Large Igneous Provinces (LIPs) in Canada Through Time and Their Metallogenic Potential. In: Goodfellow, W.D. (ed.), Mineral Deposits of Canada: A Synthesis of Major Deposit-Types, District Metallogeny, the Evolution of Geological Provinces, and Exploration Methods. Special Publication 5, Mineral Deposits Division, Geological Association of Canada (in press).

Ernst, R.E. and Buchan, K.L., 1997. Giant radiating dyke swarms: their use in identifying pre-Mesozoic large igneous provinces and mantle plumes. In: Mahoney J., Coffin M. (eds.), Large Igneous Provinces: Continental, Oceanic, and Planetary Volcanism. Geophysical Monograph Series, vol. 100, American Geophysical Union, pp. 297-333.

Ernst, R.E. and Buchan, K.L., 2001a. Large mafic magmatic events through time and links to mantle-plume heads. In: Ernst, R.E., and Buchan, K.L. (eds.), Mantle Plumes: Their Identification Through Time. Geological Society of America Special Paper 352, pp. 483-575.

Ernst, R.E. and Buchan, K.L. 2001b. The use of mafic dike swarms in identifying and locating mantle plumes. In: Ernst, R.E., and Buchan K.L. (Eds) Mantle Plumes: Their Identification Through Time. Geological Society of America Special Paper 352, pp. 247-265.

Ernst, R.E. and Buchan, K.L., 2002, Maximum size and distribution in time and space of mantle plumes: evidence from large igneous provinces Journal of Geodynamics v. 34, pp. 309-342 [Erratum, 2002, v. 34, pp. 711-714].

Ernst, R.E. and Buchan, K.L., 2004. Large igneous provinces (LIPs) in Canada and adjacent regions: $3 \mathrm{Ga}$ to present. Geoscience Canada, v. 31, pp. 103-126.

Ernst, R.E.and Buchan, K.L., 2005. Strategies for recovering the'lost' oceanic large igneous province (LIP) record of Paleozoic-Proterozoic time. American Geophysical Union, Fall 2005 meeting.

Ernst, R.E., Head, J.W., Parfitt, E., Grosfils, E., and Wilson, L., 1995. Giant radiating dyke swarms on Earth and Venus. Earth-Science Reviews, v. 39 pp. 1-58.

Ernst, R.E., Buchan, K.L., and Campbell, I.H., 2005. Frontiers in Large Igneous Province research. Lithos, v. 79, pp. 271-297.

Ernst, R.E., Wingate, M.T.D., Buchan, K.L., and Li, Z.X., 2007. Global record of 1600-700 Ma Large Igneous Provinces (LIPs): implications for the reconstruction of the proposed Nuna (Columbia) and Rodinia supercontinents. Precambrian Research, in press.

Foulger, G.R., 2007. The "plate" model for the genesis of melting anomalies. In: Foulger, G.R. \& Jurdy, D.M. (eds.), Plates, Plumes, and Planetary Processes. Geological Society of America Special Paper 430. (in press).

Gibson, S.A., 2002. Major element heterogeneity in Archean to recent mantle plume starting heads. Earth and Planetary Science Letters, v. 195, pp. 59-74.

Halls, H.C., 1982. The importance and potential of mafic dyke swarms in studies of geodynamic processes. Geoscience Canada, v. 9, pp. 145-154.

Hanson, R.E, Crowley, J.L., Bowring, S.A., Ramezani, J., Gose, W.A., Dalziel, I.W.D., Pancake, J.A., Seidel, E.K., Blenkinsop, T.G., and Mukwakwami, J., 2004. Coeval large-scale magmatism in the Kalahari and Laurentian cratons during Rodinia assembly. Science, v. 304, pp. 1126-1129.

Hatton, C.J., 1995. Mantle plume origin for the Bushveld and Ventersdorp magmatic provinces. Journal of African Earth Sciences, v. 21, pp. $571-577$. 
Hawkesworth, C. and Scherstén, A., 2007. Mantle plumes and geochemistry. Chemical Geology (in press)

Hofmann, A.W., 1997. Mantle geochemistry: the message from oceanic volcanism. Nature, v. 385, pp. 219-229.

Isley, A.E. and Abbott, D.H., 2002. Implications of the temporal distribution of high-Mg magmas for mantle plume volcanism through time. Journal of Geology, v. 110, pp. 141-158.

Ingle, S. and Coffin M.F., 2004. Impact origin for the greater Ontong Java Plateau? Earth and Planetary Science Letters, v. 218, pp. 123-134.

Ivanov, A.V., 2007. Evaluation of different models for the origin of the Siberian Traps. In : Foulger, G.R. and Jurdy, D.M. (eds.), The Origins of Melting Anomalies: Plates, Plumes, and Planetary Processes Geological Society of America Special Paper 430 (in press).

Jerram, D.A. and Widdowson, M., 2005. The anatomy of Continental Flood Basalt Provinces: geological constraints on the process and products of flood volcanism. Lithos, v. 79, pp. 385-405.

Kerr, A.C. and Mahoney, J.J., 2007. Oceanic plateaus: problematic plumes, potential paradigms. Chemical Geology (in press).

Kinnaird, J.A., 2005. The Bushveld Large Igneous Province. www.largeigneousprovinces.org/LOM.html [May 2005].

Kjarsgaard, B.A., 2007. Kimberlite Diamond Deposits, in Goodfellow, W.D. (ed.), Mineral Deposits of Canada: A Synthesis of Major Deposit-types, District Metallogeny, the Evolution of Geological Provinces, and Exploration Methods. Special Publication 5, Mineral Deposits Division, Geological Association of Canada (in press).

Larson, R.L., 1991. Latest pulse of Earth: Evidence for a mid-Cretaceous superplume. Geology, v. 19, pp. 547-550.

Li, Z.X., Li, X.H., Kinny, P.D., Wang, J., Zhang, S., and Zhou, H., 2003. Geochronology of Neoproterozoic syn-rift magmatism in the Yangtze caton, South China, and correlations with other continents: evidence for a mantle superplume that broke up Rodinia. Precambrian Research, v. 122, pp. $85-109$.

Li, X.H., Su, L., Chung, S.-L., Li, X.Z., Liu, Y., Song, B., and Liu, D.Y., 2005. Formation of the Jinchuan ultramafic intrusion and the world's third largest Ni-Cu sulfide deposit: Asociated with the $\sim 825$ Ma South China mantle plume? Geochemistry, Geophysics, Geosystems. G3 6, no. 1, Q11004, doi:10.1029/2005GC001006.

MacHattie, T., Heaman, L., Creaser, R., Skulski, T., and Sandeman, H., 2004. Remnants of an Archean Large Igneous Province: Evidence from the komatiite-bearing greenstone belts of the northern Rae domain, Nunavut, Canada. www.largeigneousprovinces.org/LOM.html [July 2004].

Manson, M.L. and Halls, H.C., 1997. Proterozoic reactivation of the southern Superior Province and its role in the evolution of the Midcontinent rift. Canadian Journal of Earth Sciences, v. 34, pp. 562-575.

Mapeo, R.B.M., Ramokate, L.V., Corfu, F., Davis, D.W., and Kampunzu, A.B., 2006. The Okwa basement complex, western Botswana: U-Pb zircon geochronology and implications for Eburnean process in southern Africa. Journal of African Earth Sciences, v.46, pp. 253-262.

Menzies, M.A., Klemperer, S.L., Ebinger, C.J., and Baker, J., 2002. Characteristics of volcanic rifted margins. Geological Society of America Special Paper 362, pp. 1-14.

Meert, J.G., 2002. Paleomagnetic evidence for a Paleo-Mesoproterozoic supercontinent Columbia. Gondwana Research, v. 5, no. 1, pp. 207-215.

Naldrett, A.J., 1997. Key factors in the genesis of Noril'sk, Sudbury, Jinchuan, Voisey's Bay and other world-class Ni-Cu-PGE deposits: implications for exploration. Australian Journal of Earth Sciences., v. 44, pp. 283-315.

Naldrett, A.J., 1999. World-class Ni-Cu-PGE deposits: key factors in their genesis. Mineralium Deposita, v. 34, pp. 227-240.

Nelson, D.R., Trendall, A.F., and Altermann, W. 1999. Chronological correlations between the Pilbara and Kaapvaal cratons. Precambrian Research, v. 97 , pp. $165-189$.

Parman, S.W. and Grove, T.L., 2005. Komatiites in the plume debate. In: Foulger, G.R., Natland, J.H., Presnall, D.C., and Anderson, D.L. (eds), Plates, plumes, and paradigms. Geological Society of America. Special Paper 388, pp. 249-256.

Pirajno, F., 2000. Ore Deposits and Mantle Plumes. Kluwer, Dordrecht, 556 p.

Pisarevsky, S.A., Wingate, M.T.D., Powell, C. McA., Johnson, S., and Evans, D.A.D., 2003. Models of Rodinia assembly and fragmentation. In: Yoshida, M., Windley, B.F. and Dasgupta, S. (eds.) Proterozoic East Gondwana: Supercontinent Assembly and Breakup. Geological Society, London, Special Publication 206, pp. 35-55.

Prokoph, A., Ernst, R.E., and Buchan, K.L., 2004. Time-series analysis of large igneous provinces: $3500 \mathrm{Ma}$ to Present. The Journal of Geology, v. 112 , pp. $1-22$.

Puffer, J.H., 2002. A Late Neoproterozoic Eastern Laurentian superplume: location, size, chemical composition and environmental impact. American Journal of Science, v. 302, pp. 1-27.
Radhakrishna, T., Joseph, M., Thampi, P.K. and Mitchell, J.G., 1990 Phanerozoic mafic dyke intrusions from the high grade terrain of southwestern India: $\mathrm{K}-\mathrm{Ar}$ isotope and geochemical implications. In: Parker, A.J., Rickwood, P.C., Tucker, D.H. (eds.), Mafic Dykes and Emplacement Mechanisms. Balkema, Rotterdam, pp. 363-372.

Reichardt, F.J., 1994. The Molopo Farms Complex, Botswana: history, stratigraphy, petrography, petrochemistry, and $\mathrm{Ni}-\mathrm{Cu}-\mathrm{PGE}$ mineralisation. Exploration and Mining Geology, v. 3, pp. 264-284.

Saunders, A.D., 2005. Large igneous provinces: origin and environmental consequences. Elements, v. 1, pp. 259-263.

Saunders, A.D., Jones, S.M., Morgan, L.A., Pierce, K.L., Widdowson, M., and Xu, Y.G., 2007. Regional uplift associated with continental large igneous provinces: the roles of mantle plumes and the lithosphere. Chemical Geology (in press).

Schissel, D. and Smail, R., 2001. Deep-mantle plumes and ore deposits. In: Ernst, R.E., Buchan, K.L. (eds.), Mantle Plumes: Their Identification Through Time. Special Paper 352, Geological Society of America, Boulder Colorado., pp. 291-322.

Sheth, H., 2006. Large Igneous Provinces (LIPs): Definition, recommended terminology, and a hierarchical classification. Journal of Volcanology \& Geothermal Research (in press).

Storey, B.C., 1995. The role of mantle plumes in continental breakup: case histories from Gondwanaland. Nature, v. 377, pp. 301-308.

Taylor, B., 2006, The single largest oceanic plateau: Ontong Java-ManihikiHikurangi. Earth and Planetary Science Letters, v. 241, pp. 372-380.

Thorne, A.M. and Trendall, A.F., 2001. Geology of the Fortescue Group, Pilbara Craton, Western Australia. Geological Survey of Western Australia Bulletin 144, 249 p.

Thurston, P.C. and Chivers, K.M., 1990. Secular variation in greenstone sequence development, emphasizing Superior Province, Canada. Precambrian Research, v. 46, pp. 21-58.

Waldron, J.W.F. and van Staal, C.R., 2001. Taconic orogeny and the accretion of the Dashwoods block: a peri-Laurentian microcontinent in the Iapetus Ocean. Geology, v. 29, pp. 811-814.

White, R.S. and McKenzie, D.P., 1989. Magmatism at rift zones: The generation of volcanic continental margins and flood basalts. Journal of Geophysical Research, v. 94, pp. 7685-7729

Wilson, L. and Head, J.W., 2002. Tharsis-radial graben systems as the surface manifestation of plume-related dike intrusion complexes: models and implications. Journal of Geophysical Research 107 (E8): DOI 10.1029/2001JE001593.

Wingate, M.T.D., Pisarevsky, S.A., and Evans, D.A.D., 2002. Rodinia connections between Australia and Laurentia: no SWEAT, no AUSWUS? Terra Nova, v. 14, pp. 121-128

Zhou, M.F., Yan, D.P., Kennedy, A.K., Li, Y., and Ding, J., 2002. SHRIMP $\mathrm{U}-\mathrm{Pb}$ zircon geochronological and geochemical evidence for Neoproteorzoic arc-magmatism along the western margin of the Yangtze Block, South China. Earth and Planetary Science Letters v. 196, pp. 51-67.

Richard Ernst was born in Philadelphia, USA and grew up in St. Louis, Missouri. After finishing undergraduate work at Wesleyan University in 1978, he was attracted north to Canada by geological field research opportunities, and he received an M.Sc. from the University of Toronto in 1981, and PhD from Carleton University in 1989. He then worked until 2003 at the Geological Survey of Canada, at which point he moved into consulting, launching Ernst Geosciences, but he also maintained academic links as an adjunct professor at Carleton University. He is co-leader of the Large Igneous Provinces (LIPS) Commission of IAVCEI (www.largeigneousprovinces.org), with a special interest in the feeder system of LIPS, analogues on Venus and Mars and LIP-associated ore deposits.

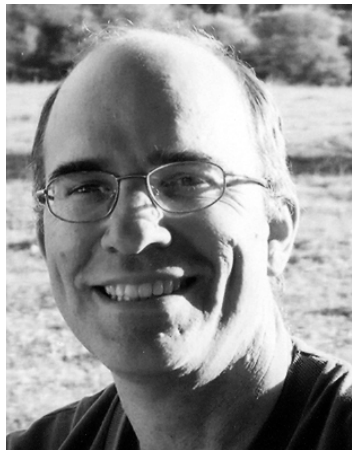

